of fresh ground rye, knead for about 20 minutes with more water and 3 small handfuls of salt. Flour hands and board and shape loaves. This should make 6 loaves of $4-5$ pounds. Bake at about $275^{\circ}$ for one to one-and-a-half hours.

Appendix II

\title{
CHARLOTTE'S WAG
}

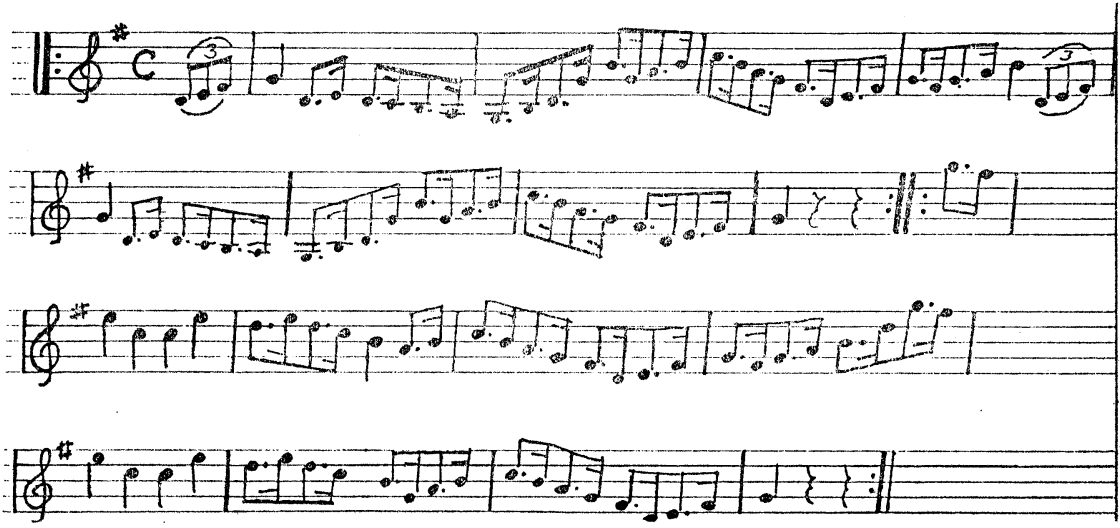

(C) Sid Blum

\section{Allen Ginsberg: The Origins of "Howl" and "Kaddish"}

Most literary people have probably first become aware of Allen Ginsberg through the media, in his self-elected and controversial role as public figure and prophet of a new age. Ginsberg's public personality has changed over the years-from the defiant and histrionic angry young man of the fifties to the bearded and benign patriarch and political activist of the sixties and seventies-but the personality has remained one that most literary people find hard to take seriously. Compare Ginsberg's reception with that of 
Norman Mailer, another writer who is also a public figure and one who, like Ginsberg, wants to replace rational with magical thinking as the mode of public discourse. Mailer's public appearances and his confessional writings characteristically begin by humiliating but end by promoting himself, and they have been enormously successful: Mailer's talents have been widely exaggerated, especially by academic critics, who already have produced several studies of his work. Mailer has succeeded because his theorizing on all matters from the digestive to the political system, no matter how bizarre or brutal the content, are developed by a kind of intellectualizing most literary people respect, even when it is adopted (as in Mailer) half in the spirit of the put-on. Ginsberg is at least as intelligent, a lot less brutal, and often a lot more self-aware, but the man who took off his clothes at a Los Angeles poetry reading, who chanted "Om" during the gassings in Grant Park at the 1968 Democratic Convention in Chicago, and who has experimented with a wide variety of drugs, strikes those manning the literary armchairs as at best a figure of fun or, more likely, a threat to western civilization. Ginsberg's role as a public figure has been part of his attempt to reassert the romantic role of the poet as prophet; but one result of it has been that his genuine literary talents and more admirable personal qualities have been obscured.

It is true that, so far, the quality of Ginsberg's writing has been too inconsistent for him to rank as a major poet. Ginsberg writes often, quickly, and, as his career has advanced, apparently without too much revision; his cult of spontaneity results in unevenness, but it also generates some of the real strengths of his writing. A poet like Eliot, carefully turning a lifetime's experience into a single volume of highly finished work, helped to create the myth (dominant when Ginsberg began to write) of the modern artist who, a literary revolutionary in spite of himself, remained a hard-working, disciplined craftsman. Like many contemporary poets, Ginsberg, an avowed revolutionary, seems much more willing to risk imperfection, even failure; what he hopes to gain is an honesty and immediacy of feeling, rather than the finish of a well-wrought work of art. When he is least successful, Ginsberg has drifted into the solipsism of purely private associations, as he does in the drug poems in Kaddish and Reality Sandwiches, or he has fallen into the predictable patterns of thought and feeling characteristic of a polemicist, as he does in much of his political poetry. But the really exciting moments in reading Ginsberg come when he breaks through to new orders in the poem and in self-understanding. "Howl" (1956), "Kaddish" (1959), "The Change: Kyoto-Tokyo Express" (1963), and "Wales Visitation" (1967) -all poems of some length, all evolving from the pressures of some personal crisis-these poems seem to me to be the main such moments in Ginsberg's career. 
Of these the most powerful-and influential-appear to be "Howl" and "Kaddish." Several poets have testified to the importance of Ginsberg's early poetry in establishing an alternative to the well-made symbolist poem that was fashionable in the fifties, and his early work does fuse two modes-the confessional and the visionary-that were to become important in the sixties. ${ }^{1}$ Not that a case for Ginsberg can only be made on historical grounds; both poems, given the intense and concentrated energy of their surrealistic language, their vivid creation of a world of primitive terrors and hallucinatory brilliance, their striking shifts of voice and mood, have genuine literary merit. For a long time, their explosive poetic energy has been missed, partly because of the distractions of a "shocking" language and matter (drugs, madness, suicide, homosexuality, incest), but mainly because many readers, still not sympathetic to the kind of form found in these poems, have accused them of an absence of form. Moreover, while they achieve literary form and attain a public impact, these poems derive from deep, long-standing private conflicts in Ginsberg-conflicts that ultimately stem from his ambivalent attachment to his mother, his difficulties in asserting a separate, independent personality. While there is a progression of self-awareness from "Howl" (1956) to "Kaddish" (1959), both works seem to me to expose rather than to resolve these conflicts, though they make valiant efforts at such resolution. Nevertheless, it is Ginsberg's ability to probe these areas of conflict that largely explains their innovative energy and powerful appeal.

Allen Ginsberg is a mystical and messianic poet with intense suicidal wishes and persistent self-doubts, a would-be spontaneous artist whose most spontaneous thoughts characteristically turn toward feelings of being stifled and inhibited-walled and bounded in-and thus toward longings for some painful, apocalyptic deliverance-ultimately death itself. To read the notebooks and journals that Ginsberg has kept from adolescence onwards is to encounter a man with grandiose hopes for himself, but one who relentlessly flaggelates himself for his failures and who tends to assume that all his undertakings will end, just as they have ended, in disaster. ${ }^{2}$ Just the published Indian Journals (kept during 1962-63) amply reveal how this outwardly serene bard is intrigued with failure and death, spending much of his time contemplating the ghats where the Indian dead are cremated. Of the Ginsberg of the late fifties and early sixties, Lawrence Ferlinghetti remembers, "he is the flippy flesh made word / and he speaks the word he hears in his flesh / and the word is Death." 3 To say all this is not to say that Ginsberg's public manner is false but that, on the contrary, it has been hard-won. And poems like "Howl" and "Kaddish" have a key place in the evolution of his personality, developing out of a time in his life when his 
creative impulses came into something like a balance with his propensities for self-destruction. As Ginsberg himself tells it-a version of his life we should approach skeptically-the story of his literary career and in a way the real story of his life begin with his removal from New York to San Francisco in 1953.

"Howl" is not-contrary to popular impression-the work of an angry young man. When he wrote the poem, Ginsberg was 30; in 1953, when he left family, friends and the established literary culture behind him in the East, he was 27-being, like his friend Jack Kerouac, a romantic wanderer who found it difficult to sever family ties. Ginsberg himself sees the 1953 journey west as a crucial and symbolic kind of act: "It was like a big prophecy, taking off for California. Like I had passed one season of my life and it was time to start all over again." 4 It was not quite this easy and final, as we shall see; but moving west was a dramatic attempt to loosen the parental grip-to free himself from pressures created by his mother's long history of psychotic illness as well as his frequently acrimonious relation with his father. Going west was, in short, a turn away from the threatening images of failure, disintegration, suffocation he associated with home-a gesture toward the future, toward life, an attempt to start all over again as his own man. Yet it is also true that Ginsberg made this journey half looking back over his shoulder-just as in "Howl" he would return to the experience and emotions of his life in New York in the late forties and in Part III of the poem ("Carl Solomon, I'm with you in Rockland.") deny that he had ever left. It is certainly mistaken to imagine a recreated Ginsberg floating into San Francisco on a magic carpet, dressed in long robes, with flowing hair, hand cymbals and a "San Francisco Poetry Renaissance" banner. The Ginsberg that emerged in "Howl"-Ginsberg the rancorous and somewhat gloomy mystic seer-must in some sense have been there, but he was apparently hidden at first beneath a deferential and conventional exterior. In fact, it would be more accurate to imagine him arriving in a three-button suit, striped tie, and an attaché case. Soon after his arrival in San Francisco, Ginsberg was looking for a job in market research, and he quickly found one. There was no reason he shouldn't-since this was precisely the kind of work he had been doing back in New York.

Not long after he secured the job, Ginsberg became involved with a woman, with whom he eventually moved into an apartment in San Francisco's posh Nob Hill district. Life went along in this style for several months in the fall of 1953-until Ginsberg began seeing a therapist at Langley-Porter Institute, a Dr. Phillip Hicks, to find out why neither the job nor the woman seemed to satisfy him. According to Ginsberg, at one point in his treatment, the doctor asked, 
"What would you like to do? What is your desire, really?" I said, "Doctor, I don't think you're going to find this very healthy and clear, but I really would like to stop working forever-never work again, never do anything like the kind of work I'm doing now-and do nothing but write poetry and have leisure to spend the day outdoors and go to museums and see friends. And I'd like to keep living with someonemaybe even a man-and explore relationships that way. And cultivate my perceptions, cultivate the visionary thing in me. Just a literary and quiet city-hermit existence." Then, he said, "Well, why don't you?"5

In several interviews Ginsberg discusses this encounter, mythologizing it into The Great Breakthrough that allowed him to start a new life. As Ginsberg tells it, the doctor's tolerant acceptance of Ginsberg's unconventional desires encouraged self-acceptance and the end of his misguided attempts to please his father-both of which, in turn, generated "Howl." So, the story goes, Ginsberg wrote a report showing how his firm could replace him with a computer; they fired him and he went on unemployment, free to enjoy a "quiet city-hermit existence." By this time he had already met Peter Orlofsky, then a student living with the painter Robert Lavigne in North Beach, and Ginsberg's increasing involvement with Orlofsky disturbed the woman he was living with. The eventual result-again not following too long after the episode with Dr. Hicks-was that Ginsberg left affluent Nob Hill for downtown Montgomery Street, to live with Orlofsky. And soon after these dramatic shifts in his life he began writing "Howl."

Yet Ginsberg's account of these events sounds suspiciously like a fantasy of a magical cure, and a reading of the journals he kept at the time reveals that even chronology has been transformed a bit to promote the myth of the Breakthrough. 6 Actually, Ginsberg continued to work at his market research job for three or four months after he moved in with Orlofsky and in so far as his journals reveal his mood at the time, they suggest he felt depressed, not liberated, when he lost his job. Moreover, while Ginsberg strongly implies that his therapy (and even the need for it) ended with his doctor's laying on of hands, the journals indicate that he continued in treatment, perhaps for as long as several months, including the time in which "Howl" was written. Moreover, the lengthy and almost daily entries from late 1954, when he first met Orlofsky, show that Ginsberg entered into this relationship with the same expectations of salvation and the same premonitions of disaster with which he then launched all his activities. An entry for April 20, 1955-written four months after he had started living with Orlofsky-vividly conveys his mood at the time, and it was not one of emancipated self-acceptance: 
Not writing enough what can I say-rapid exchange of events, jobloss, peterloss,-isolation, no one I love loves me no contact, the isolation -facing loss of Jack [Kerouac] and Bill [Burroughs] as previous loss of contact with L-the myths held for the decade to fill time. ${ }^{7}$

"Howl" does affirm its author's capacity to survive an agonizing ordeal; yet the poem is charged with equally strong feelings of personal and literary failure, isolation and, most powerfully, loss, the feelings of this journal entry and many others like it. In fact, both "Howl" and "Kaddish" react to loss in precisely the way suggested in the journal-not by acceptance and working through the loss, but by idealizing, mythologizing, the lost object ("the myths held for the decade to fill time").

In addition, a more careful look at what Ginsberg tells of the transaction with his psychiatrist suggests a different interpretation from the one supplied by Ginsberg himself. In this encounter, he has clearly transferred onto the doctor, speaking to him as if he were speaking to his father, confessing his intimate feelings about work, about homosexuality, about "visionary" or hallucinatory experiences that he (like his mother) had experienced. He knows his father disapproves of all this, and he disapproves himself of these impulses, but projects such criticism onto the doctor: "I don't think you're going to find this very healthy and clear." He expects to be denounced, but what he hears is what he always wanted to hear from his father-permission. Permission is not, however, the only possible interpretation of the doctor's "Well, why don't you?"-a remark that could have led Ginsberg to examine his inhibitions and, ultimately, the origins of his wishes, all yearnings that, as we shall see, align him with the mother, against the father. The doctor, Ginsberg revealingly comments, gave him "the authority, so to speak, to be myself"-as if this authority were external to him. ${ }^{8}$ In Young Man Luther, Erik Erickson points out that young men in a state of "identity diffusion," as Ginsberg clearly was at this time, often transform their therapy into "something like Jacob's struggle with the angel, a wrestling for a benediction which is to lead to the patient's conviction that he is an alive person, and, as such, has a life before him."9 Ginsberg, seemingly satisfied with a "benediction" rather than a fuller exploration of his wishes and fears, temporarily wrestles himself "free" from guilt-but remains dependent upon the authority of the forgiving father for permission to be himself. In this exchange we can see some of the motives for Ginsberg's own later adoption of the role of the tolerant, benign patriarch toward younger people-while he himself continually turns toward older men (from Martin Buber to Swami Shivananada) in search for reassurance that he does indeed have the authority to be himself, a right to a life of his own. 
It should come as no surprise that by virtue of moving across the country and acquiring an idealized father figure in his doctor, Ginsberg had accomplished a less than complete break with his past. Both the removal to a "safe" distance and the supportive context of therapy probably helped him more to explore, rather than shed, the past, and it was the very insistence of his private life as the material for his poetry that pushed Ginsberg away from the predominant idea of the poem as impersonal artifact and toward a sense of the poem as confessional outpouring. In reality the Ginsberg of the late fifties manifests a powerful wish to strike out on his own, along with an equally powerful fear of freedom. A poem like "Howl" angrily asserts the "real" self of its author, the "angel-headed hipster" persecuted by social and paternal authority, and the poem does so with a kind of tormented exhilaration that suggests the release of long-repressed feelings. More a cry of pain than of anger, "Kaddish," an elegy for Ginsberg's mother, also seeks to affirm a new and separate life for the poet. Yet for all of the rebelliousness of "Howl" and all the protestations of accepted loss in "Kaddish," both poems view independent life (in the language of the journal) as "isolation" and "loss." Independence and submission, struggling toward the future and being drawn back into the past: such are the conflicts that inform the best of Ginsberg's poetry-in ways that we can see even more clearly by examining the dynamics of his attachments to both his parents.

Anyone who has met Louis Ginsberg or heard him read his poems at one of the joint readings he's given with his son will have encountered a short, sturdy man well into his seventies, with large inquiring eyes and a slightly frowning, rather oppressed expression. At first glance he seems, in his poems as well as his person, a modest and mild man, a very likely candidate for just that kindly, forgiving father that Ginsberg wished for, a man whose weakness might be a reluctance to assert his authority rather than in withholding his sympathy. Yet the attitude of mutual respect which the two men now display toward each other has the quality of an uneasy truce which, if unlikely to break into open hostilities is still filled with critical sniping from both sides. At least this is the impression created by Jane Kramer in her Allen Ginsberg in America, especially in her report of a Sunday morning conversation in Paterson, prior to one of their father/son reading performances. Louis inquires if Allen has "some good clothes for the reading tonight," twits his son for not being home enough, scolds him for not writing enough when away, denounces the lack of discipline in Allen's life and poetry, and alludes uneasily to his son's greater fame. Allen himself, showing perhaps more discipline than his father credits him for, responds with gentle tolerance, even when the issues become a little more charged. At one point, after Allen's friend Maretta announces that her sadhana is hashish, Mr. Ginsberg asks, 
“What's with this Maretta? Why can't you bring home a nice Jewish girl?"

Ginsberg, laughing, threw up his hands. "For the love of God, Louis," he said, "here for years you've been saying, "Please, just bring home a girl for a change,' and now that I do, you want a Jewish one?"

"You're such an experimenter, Allen," Mr. Ginsberg said. "Tibetan Buddhist girl friends. Swamis, Drugs. All this talk from you about pot -'It's so elevating, Louis. So ecstatic. My soul is outside my body. I see ultimate reality." Mr. Ginsberg frowned. "You know what I say? I say, 'Allen, take it easy.'"10

With Louis in his seventies and Allen nearing 40, the father still does not accept the son's style of independence, while the son's experimental style itself seems arrived at as a direct challenge to the father's authority and a test of his love. In this exchange the most sensitive and persistent issues between the two are touched on-family loyalty, drugs, homosexuality, visions of ultimate reality-in a manner that suggests a mollifying (here through humor) of conflicts that were earlier expressed with much more acrimony. In John Clellon Holmes' novel of the Beat Generation, Go-a book he says he tried to make as factually accurate as possible-the conversations between David Stofsky (Ginsberg) and his father seem to represent the original clashes, ritualistically repeated on a much later Sunday morning in Paterson.

When [Stofsky] got home, he announced to his father that he had "visions," and when this brought forth little more than a pseudo-literary reaction, he appended, reckoning on its effect, that he was afraid he was going mad. His father rewarded him with the same sort of hysterical outburst that had seized him when, after several weeks of hesitant feelers, Stofsky had confessed his homosexuality. The two had an uneasy relationship anyway, at the bottom of which was mutual distrust, and when they were together they invariably squabbled over philosophical matters or Stofsky's "evil companions of the city" (as his father called them $) .11$

The Allen Ginsberg Archives at Columbia contain an incomplete but still quite extensive correspondence between the father and son, dating from Allen's days at Columbia in the mid 1940s down to the early seventies. Much of the correspondence is given over to intricate and often heated political, moral, and literary debates. At a time when his son, still an undergraduate, was self-consciously identifying himself as a decadent and ardently reading such advanced modern thinkers as Gide, Spengler, Rimbaud, 
and Baudelaire, Louis advised: "A little of the Greek ideal of moderation would do you no harm, m'lad"; ${ }^{12}$ and the father's perspective can be briefly characterized as a deliberate cultivation of a moderate, well-balanced, practical approach to life, though with a decided tilt toward the cautionary in his dealings with his son. Once in a while, the father explodes. As late as 1955, with Allen nearing 30, Louis wrote: "All your vehement, vaporous, vituperations of rebellion move me not one jot. Your attitude is irresponsible-and it stinks." 13 In a much earlier letter, probably written during Ginsberg's second year at Columbia, the father proposes the safety of accommodation and warns against precisely those "deviant" routes his son was to take up.

Even if normal values are rationalizations as well as abnormal ones, the latter, as normal values qua normal ones, result in a better and safer adjustment to society and a greater integration of the person. According to your blanket statement, you would bracket the rationalizations of a homosexual or an insane person as satisfactory for society and for the person. The homosexual and the insane person is a menace to himself and to society. Danger and disaster lie that way! Your clever verbal solutions are incongruous with [the] reality of life. You are developed intellectually; but, emotionally, you lag. ${ }^{14}$

In his letters, as in his poetry, Louis Ginsberg's manner is characteristically sententious; but his timeless truths are often avowedly based either on the authority of his greater experience in the world or appeals to the "safety" of his position rather than its intrinsic value. The letters show a genuine concern for a troublesome son, but it is also easy to see how his son might get the impression that the father holds that truth can be arrived at by carefully examining both sides of every question, then coming down resoundingly in favor of the status quo. The trouble with Allen's undergraduate literary hero Rimbaud, his father tells him, is that the French poet sought "absolute moral values" rather than "adequate moral values." 15 At about the same time, just after reading Karl Shapiro's Essay on Rime, Louis asserted that, of course, modern poets reject the "superstitions in religious faith" and they detect the hypocricies beneath the surface mores of contemporary society, BUT they should not leap to pessimistic conclusions: they must remain "clear-headed" enough (unlike Allen) to reject "decadence" as well and opt for "pragmatic values." "Concluding, I say, Allen, suspend your judgment; walk balanced between the seen world and the unseen one; and take care of your health!"16 In fact, in the letter warning against Rimbaud, Louis had pronounced that one "must resign himself to pragmatic values or commit suicide."17 
But the son, who later was to solve the problem of values by adopting a "religious faith," not only refused to suspend his judgment; he asserted radical views, declaring, for instance, all modern civilization corrupt and disintegrating. Such views the father dismisses, in a key term, as "off-balance." 18 It is clear that each, questioning the other's love, questions the other's sense of reality and demands that the other "see things as I do." A visionary poem sent to Louis in 1958 is judged as "brilliantly myopic."19 In their long cold war political debate beginning in the late fifties, Allen is accused of distorted vision, which makes him too harsh on the United States and too easy on Soviet Russia. And in their ongoing literary arguments, attitudes of parental caution again clash with adolescent egotism and rebellion. The older man conceives of poetry as a practical craft, generated by emotion and shaped by individual vision but designed to effect immediate commuication with a fairly wide audience and hence comfortably drawing on traditional resources of technique and language. Louis Ginsberg, a steadfast traditionalist after 40 years of modernist experiment, likes verse "neat, / Exact, / Compact- / To file / My style / And pare / It bare"; ${ }^{20}$ but the son who, as we shall see, feels he can only really identify himself in acts that shatter established boundaries (of self, of literary form), insists on poetic means that are more ample, more free-and more grandiose. In a follow-up letter on the Shapiro poem, Louis attacks modernist verse as "willfully obscure," unnecessarily creating a "gulf between the poet and the intelligent reader."21 In his view, "the ideal of a poem is that it give a general meaning to the many and a deeper and more complex experience to the few," an ideal enacted in his own practice. ${ }^{22}$ Moreover, the letters frequently offer comments on exchanged poems: Allen's earliest verses are often praised, but just as often criticized as too "knotty," "impacted," "inchoate"-in a word, obscure. ${ }^{23}$ Again the message is that the son should quit his pretentious inaccessibility, his literary decadence, and accommodate himself to his audience. "Not bad advice," anyone who has read these poems might conclude, but it no doubt struck the young poet as philistine old fogeyism. Allen's poems are faulted, however, on deeper than stylistic grounds; their "false assumptions" about life are questioned as well. ${ }^{24} \mathrm{~A}$ key instance is Louis Ginsberg's reaction to "Howl," a poem in which his son publicly admitted to the very hallucinations, drug use, and homosexuality his father had warned him against. Significantly, Ginsberg sent a copy of the poem to his father not too long after its completion, as if the poem, far from being simply a pure and naked confession of Ginsberg's inmost soul, made some kind of hostile reference, and perhaps an appeal, to the father, who responded with a characteristically balanced assessment. " 'Howl," he wrote, "is a wild, volcanic, troubled, extravagant, turbulent, boisterous, unbridled outpouring, intermingling gems and 
flashes of picturesque insight with slag and debris of scoriac matter. It has violence; it has life; it has vitality. In my opinion, it is a one-sided neurotic view of life; it has not enough glad, Whitmanian affirmations." 25 The poem does have emotional force, vitality, BUT its vision of life is, again, off-balance, sick-"one-sided" and "neurotic" in its angry disillusionment.

In view of the deep, persistent, and often acrimonious conflicts between the two men, it is tempting to read "Moloch," the wrathful child-devouring deity of "Howl," as an angry representation of the father. But to derive from the poem a picture of the author as the essentially innocent victim of sadistic, persecutory authorities is to derive exactly the picture the author would like us to carry from the poem. "Howl" may be an honest confession of Ginsberg's conscious feelings at the time he wrote it, but many of the poem's rebellious attitudes actually serve as a defense against feelings that he is less able or willing to admit. It is true that Louis Ginsberg became the focus for many of his son's resentments, and while many of these grievances really derived from other sources, the anger also had some genuine basis in reality, as did his criticisms of the social system. Even their correspondence, where conflicts might be more in abeyance than in personal encounters, reveals paternal vituperation and ultimatums-e.g., a letter sent to Allen in the summer of 1948 which consisted simply of the sentence "Exorcise Neal," a reference to Ginsberg's erotic attachment to Neal Cassady at the time ${ }^{26}$-and the father seems to have insisted upon the son's successful completion of college and his becoming, as Allen put it, "a fine upstanding completely virile son." 27 Moreover, the father often questions not just his son's judgments but his very mental balance, a sensitive issue given his mother's history of psychotic illness.

Yet if Allen feared his father as a severe judge and angry persecutor, it is also clear that he felt a deep attachment and admiration for Louis Ginsberg, the origin of the recurrent image of the idealized, tender father in his poetry. It was his father, after all, who introduced Ginsberg to poetry and literature, an area in which Louis himself seemed to display real mastery and which his son was to make his own life's work. Moreover, Naomi Ginsberg was a mother who was often emotionally or even physically absent -or frighteningly present. As Louis Ginsberg remembers in a memoir called "My Son the Poet,"

In the early years of my marriage, a shadow of sorrow fell on our family. My wife, Naomi, somehow developed a neurosis, which, as the years went on, thickened into a psychosis. She would spend two or three years in a sanitarium, then I'd take her out for half a year or a 
year. After that, ominous hints of her worsening condition made me take her back.

Once, when he had decided to take her back to the hospital, she threatened, then attempted suicide, slashing her wrists in the bathroom.

She opened [the door] and came out with blood oozing at both wrists. They were surface cuts, so I bandaged them and got her to bed. The boys stood there, shivering in their night clothes, panic in their eyes. What traumas, I thought, might sink into them and burrow into their psyches. $^{28}$

In view of Naomi Ginsberg's illness, apt to make her rigid in her expectations of her son's behavior and unpredictable in her own, it is likely that her son turned to his father as a refuge, hoping to find both a point of stability in the family and a benign protector. And it is in such yearnings for (and memories of) a tender attachment with a tolerant older male that we find the beginnings of Ginsberg's later search for a kind of maternal father, of the sort he felt he'd found in Dr. Hicks in San Francisco and in such literary mentors as Whitman and Blake. "The Father is merciful," Ginsberg ecstatically proclaims in "Transcription of Organ Music"; what he continually seeks is some mild, accepting, Christ-like saviour, who will protect him from the terrifying aspects of the mother and offer the tender acceptance that she does not. Seeking salvation from the father (rather than reconciliation with him) inevitably led to disappointment, but even during the bristly period of his adolescence, Ginsberg clearly courted the older man's love and approval by striving to perform "good works." If Allen could condemn his father's assessment of one of his short stories as "a symptom of the smug normalcy of the bourgeois intellectual attitude," he assured his father in the same letter that he was no longer cutting classes, indeed was dressing decorously (even wearing a conservative black tie) and had "started to really get an education, making the most of the College by returning unread to the library" all his volumes of Gide and Baudelaire. ${ }^{29}$ Similarly, when he wrote a few years later that he was postponing his final term at Columbia, he explained that he was doing so in order to save enough money to start psychoanalysis, a course earlier suggested by the father himself. "Don't worry about me becoming a permanent wastrel just because I'm trying to 'save my soul' as scientifically as possible," he wrote. ${ }^{30}$

Such yearnings to yield to the father (or his surrogate, the psychiatrist) also threaten Ginsberg, however real his attachment and his desire to please. For Ginsberg's basic image of the father, during adolescence and 
early manhood, is neither that of the powerful foe nor that of the benign protector, but that of a timid, rather withdrawn man, one who, with his cult of practicality and normality, has himself surrendered to external pressures and is thus finally feared not because he is too powerful, but because he is not strong and certain enough to save his son. The picture of Louis Ginsberg we get in "Kaddish" is that of an introverted, neglectful man, frightened, worried, and humiliated by his wife's paranoid hallucinations but whose attention, it seems, can only be caught by such apocalyptic means. In this view, mother and son are linked as victims of the father's weakness and neglect; the final impression of the father is one of ineffectuality, inconsequence: Naomi Ginsberg, the psychotic mother rather than the poet-father, is celebrated as her son's muse. Moreover, Louis Ginsberg was a literary intellectual and writer who taught English in the high schools of Paterson and who published poems in places like the editorial pages of the New York Times and the Herald-Tribune. What may have seemed like impressive accomplishments to a very young boy must have come with the increasing sophistication (and grandiosity) of adolescence, to signify a singular lack of daring and ambition. It is not too surprising, therefore, to find in the introduction that Ginsberg wrote to the father's collection, Morning in Spring (1968), that beneath the affectionate respect with which the now world-famous son writes of his father, we should hear persistent hints of disappointment. "Living a generation with lyrics wrought by my father, some stanzas settle in the memory as perfected," Ginsberg opens. ${ }^{31}$ This (uncharacteristically) deliberate, well-formed sentence carefully defines an attitude of respectful but hardly enthusiastic admiration, a striking contrast to Ginsberg's frequently effusive praise of such of his contemporaries, like Jack Kerouac, who share his own ultimate assumptions. The son, remembering "some stanzas" but apparently no whole poems, is clearly not going out on any critical limbs for the old man, whose well-balanced views are now turned back on him. As soon as Louis Ginsberg is introduced, he is pitted (in a losing battle) against W. C. Williams. "'In this mode perfection is basic,' W. C. Williams wrote, excusing himself for rejecting my own idealised iambic rhymes sent him for inspection." ( $p$. 11). Imitating Louis' idealized verses, Ginsberg went astray-until he was saved by a bolder, and more successful guide. In fact, in the first three pages of the introduction, Ginsberg mentions Williams and Pound four times each, every time making an invidious comparison between their boldness and his father's timidity. Says Ginsberg of his father's kind of poetry:

I have resisted this mode as an anachronism in my own time-the anachronism of my own father writing the outworn verse of previous century voices, reechoing the jaded music and faded effect or senti- 
ment of that music in a dream-life of his own sidestreet under dying phantom elms of Paterson, New Jersey-at the very time that Paterson itself was (having been articulated to its very rock-strata foundations and aboriginal waterfall voice in W. C. Williams' epic) degenerating into a XX Century Mafia-Police-Bureaucracy-Race-War-NightmareTV-Squawk suburb. (p. 14)

While Williams dauntlessly combines primitive solidity with an awareness of contemporary social reality, Louis Ginsberg neglects the present, timidly withdrawing into the "dream-life" of his peaceful suburban street. It is not just that this establishes him as an irrelevant "anachronism," an unreliable guide for a young man entering a bewildering world; the cost of such withdrawal is finally the loss of real autonomy and even life. The father's guiding voice is hollow, a mere echo, not his own voice: Daddy is nobody. All the language associated with Louis Ginsberg in this passage-“anachronism," "outworn," "jaded," "faded," "dying phantom elms"-suggests death, as if the life had been sapped out of him. The son may take a certain satisfaction in such diminishing thoughts of that parental authority whose judgments he feared. Yet disappointment with the defeated actual father generates the "Pater Omnipotens Aeterna Deus" of "Howl," the "Lord" of such poems as "Kaddish," "Laughing Gas" and "Magic Psalm"-all fantasies of an all-powerful father whose strength can heal and direct the writer. So, during the early phase of Ginsberg's career, the earthly father, whose "failure" the son anxiously seeks to avoid for himself, becomes a negative model, ironic source for the bardic grandiosity, literary experimentation and daring self-exposures that characterize his son's poetry starting with "Howl." In fact, what Ginsberg appears to have done in 1955 was to take up his father's medium of communication (poetry) and, declaring it hollow and dead, transformed it by infusing it with the hallucinatory visions and human vulnerability of his mother.

"You still haven't finished with your mother."

Elise Cowen to Allen Ginsberg, after typing the manuscript to "Kaddish." 32

"If only you knew

How your poet son, Allen,

Raves over the world,

Crazed for love of you!"

Louis Ginsberg, "To a Mother Buried."33

One reason for Ginsberg's disenchantment with his father is that he often looked at the older man through the terrified-and rancorous-eyes of his 
mother. In examining the kind of grip Naomi Ginsberg had on her son's feelings the key document is "Kaddish," a confessional/visionary/elegaic poem in five parts in which Ginsberg (like Sylvia Plath in "Daddy") attempts to transform literature into therapeutic magic: to exorcise the ghost of a parental influence. Neither of the two poems, for all their literary brilliance, succeeds in delivering the poet from the agonizing conflicts that generate the work in the first place, although Ginsberg comes closer. "Daddy" may heighten hatred into a form of hard eloquence, but the poem is pure anger and destruction, with the renounced father simply transformed from a god-like to a satanic figure: Plath, whose father died when she was just nine, was never able to make the crucial step of perceiving him as a human rather than a mythical figure. In "Kaddish" Ginsberg confronts his anger at his mother's abstraction from life, her abandonment of him in madness, his disgust with her careless physical habits, his fascination with her sexually seductive manner with him, his guilt about his treatment of her during her breakdowns-"Kaddish" lays bare all these feelings and then proceeds to a declaration of love for Naomi Ginsberg. In the poem there is, as Ginsberg announces at the start of Part II, a "release of particulars," and Naomi Ginsberg is encountered with elaborate and moving specificity, as a complex human figure. ${ }^{34}$ Yet it is also true that by the end Ginsberg has not resolved his divided feelings about his "fatal Mama" (p. 27) as much as he claims; the poem tempts us to think, like certain forms of therapy, that to get feelings out is to resolve them. But in fact the poem, far from moving toward idealization of the mother, culminates with an apotheosis of death (as release from the agonizing conflicts of life) and a yearning for fusion with this lost parent.

Naomi Ginsberg, a member of the Communist Party from the time of her youth, believed her life was in danger from political authorities such as Hitler, Roosevelt, and the F.B.I. as well as family figures, notably her mother and her husband. Her fears characteristically concerned an invasion of her self by some external, invisible, and malevolent agency that could subtly creep inside and possess her: poison gas filtering its way under the door, the manipulation of her thoughts by means of three bars inserted in her back and wired to her brain by the F.B.I. during one of her stays in the hospital. In "Kaddish" Ginsberg seems to understand these fantasies of political persecution as extensions of sexual fears and, though Ginsberg himself never says so, it would be natural for a young boy to equate these fears of violation with some assault by the father. In any case, Naomi Ginsberg's paranoia was the dark side of what her son calls her "mad idealism" (p. 24), her intense yearning for the Pure, the Beautiful, the Ideal evident in her nostalgia for the innocence of her girlhood, her political utopianism (which inspired her to write Communist fairy tales-p. 16), her alternately 
dreamy and paranoid paintings ("Humans sitting on the grass in some Camp No-Worry summers yore-saints with droopy faces and long-ill-fitting pants"-p. 25), her romantic songs played on the mandoline ("Last night the nightingale woke me / Last night when all was still / it sang in the golden moonlight / from on the wintry hill"). As a boy Ginsberg must have admired her intensity, been awed by the loftiness of her idealism, and shared her fears of the father's "assaults."

Yet both the fears and the longings of Naomi Ginsberg dissociated her from immediate emotional realities; what made her admirable also made her distant, bewildering, even terrifying-and made her son angry. She, too, neglected Allen. "I will think nothing but beautiful thoughts," says Naomi in "Kaddish," and she tells her son of seeing God the day before: "I cooked supper for him. I made him a nice supper-lentil soup, vegetables, bread \& butter-miltz. ..." At that very moment she is serving Allen "a plate of cold fish-chopped raw cabbage dript with tapwater-smelly tomatoes-week-old health food . . . I can't eat it for nausea sometimes" (p. 2). "Kaddish" frequently refers to such nausea-inspiring meals. Naomi was not providing Allen with true sustenance: a son cannot live on beautiful thoughts alone. Moreover, not only did his mother fail to take care of him, Ginsberg was forced at crucial points in her illness to take care of her. In Allen's version at least, his father and older brother evaded the reality and responsibilities of Naomi's madness, thus leaving the youngest son with the excrutiating practical problems of dealing with her illness. Both times she was hospitalized during Ginsberg's lifetime, he was the one who had to take her to a rest home or, worse, call the police for help. The first of these two episodes took place when Ginsberg was just 12. At exactly that delicate point of transition between boyhood and manhood, between home and the world, independence and responsibility were thrust on him, leaving him frightened, resentful, uncertain, and tormented with guilt. At that time, when his mother started hallucinating "a mystical assassin from Newark" (p. 13), Ginsberg, who had stayed home from school because she seemed so nervous and distraught, called a doctor, who recommended a rest home. After a long, humiliating bus ride, after being thrown out of one rest home (because Naomi hid in the closet and demanded a blood transfusion), Allen finally left her alone in an attic room, got on the next bus home and "lay my head back in the last seat, depressed-the worst yet to come?-abandoning her, rode in torpor-I was only $12 . "$

12 riding the bus at nite thru New Jersey, have left Naomi to Parcae in Lakewood's haunted house-left to my own fate-sunk in a seat-all violins broken-my heart sore in my ribs-mind was empty-Would she were safe in her coffin-(p. 15) 
The sequence of feeling here-from guilt at abandoning her, to pity for his own isolated fate, to exhaustion and apathy and finally to the wish that she would die-reveals Ginsberg's desire to be relieved of his mother and the conflicts she triggers in him. And the worst was yet to come; that night,

the telephone rang at 2AM-Emergency-she'd gone mad-Naomi hiding under the bed screaming bugs of Mussolini-Help! Louis! Buba! Fascists! Death!-the landlady frightened-old fag attendent screaming back at her (p. 17).

Ginsberg, who had already been criticized by his father for leaving her there, asks himself, "my fault, delivering her to solitude?" It's a possible question: Ginsberg nowhere says exactly why he left her, it was not something he had to do, he describes himself sitting on her bed "waiting to escape," and has wished her dead. The situation, filled with painful stresses even for an adult, must have seemed unbearably complex for a boy of 12 .

Later, visiting her in the hospital, Ginsberg was confronted with Naomi "begging my 13-year-old boy mercy," saying

'Take me home'-I went alone sometimes looking for the lost Naomi, taking Shock-and I'd say, "No, you're crazy Mama,-Trust the Drs." - (p. 19),

and still later, just before her last hospitalization in the late forties, as Naomi imagines herself hounded by Louis and her own mother,

'-No wires in the room!'-I'm yelling at her-last ditch, Eugene listening on the bed-what can he do to escape that fatal Mama-'You've been away from Louis for years already-Grandma's too old to walk-' We're all alive at once then-even me \& Gene \& Naomi in one mythological Cousinesque room-screaming at each other in the Forever-I in Columbia jacket, she half undressed.

I banging against her head which saw Radios, Sticks, Hitlers-the gamut of Hallucinations-for real-her own universe-no road that goes elsewhere-to my own-No America, not even a world-(pp. 26-27)

Even at this point much later in adolescence, Ginsberg emphasizes the way his mother's madness removed her into a private, hallucinatory world ("her own universe") where, beyond all hysterical screaming, she remained inaccessible ("no road that goes nowhere"). In her madness Naomi triumphantly transcended reality, but abandoned her son, who, similarly deserted by his father and brother, was left in the position of asserting reality, 
angrily denying the validity of her visions and delivering her over to those very authorities-doctors and police-she most feared. In a situation filled with exhausting stresses Ginsberg reacted with remarkable strength. In "Kaddish" he asks, "Louis what happened to your heart then?"-when he was confronted with his terrified wife shrieking that he had called out the "poison cops": "Have you been killed by Naomi's ecstacy?" Allen was not but he suspected a certain hardness in his strength, this intensifying the guilt already latent in the situation; "It's my fault," he must have felt, "if I had loved my mother more, this wouldn't have happened to her-and to me." As an adolescent, Ginsberg was left alone, searching for that "lost Naomi" who had nurtured him as a young boy, fearing those ecstatic hallucinations of the "fatal Mama" that seemed to kill all feeling between them, and yet longing to join her in the dramatic intensity and transcendence of her madness.

From the retrospective point of view of the adult poet, the ideal way to handle this excruciating situation would be to accept a certain amount of anger and vindictiveness as natural, to emphasize the positive strength and tenderness that Ginsberg did show and so to view a certain amount of "hardness" as a prerequisite for self-survival; but this is by no means what we find in "Kaddish," where unresolved feelings of guilt prompt the poet to exorcise her spirit and be rid of her at last-a maneuver that breaks down, however, in view of his even stronger desire to return and fuse with her in death. The deepest sources of this longing we can see in a crucial passage of "Kaddish":

One time I thought she was trying to make me come lay her-flirting to herself at sink-lay back on huge bed that filled most of the room, dress up round her hips, big slash of hair, scars of operations, pancreas, belly wounds, abortions, appendix, stitching of incisions pulling down in the fat like hideous thick zippers-ragged long lips between her legs -What, even, smell of asshole? I was cold-later revolted a little, not much-seemed perhaps a good idea to try-know the Monster of the Beginning Womb-Perhaps-that way. Would she care? She needs a lover. (p. 24)

At first glance this passage seems a daring revelation of an incest wish and a shockingly realistic description of the mother's body. But what we really see here is how one post-Freudian writer, pretending to be open and at ease about incestuous desire, affects sophisticated awareness as a defense against intense longings and anxieties. The lines are charged with feelings that the poet, far from "confessing out," appears eager to deny. Ginsberg's tone of voice is noticeably more defensive than frank: he assumes an atti- 
tude of detached superiority toward the scene-idealizing the act into a mythical / psychological experiment ("know the Monster of the Beginning Womb") performed more for his mother's emotional gratification than his: "She needs a lover." All of the sexual initiative is attributed to Naomi, allowing her son, innocent in his sophistication, to view himself as a superior, liberated, and compassionate individual, beyond conventional moral restraints and thus willing and able to give a little help to one of his friends. Holding himself above this emotionally charged situation, Ginsberg seeks to deny both the powerful attraction he feels toward his mother-as well as the fears he experiences as soon as he imagines the possibility of acting on it. The persistent emphasis on scars, particularly on wounds made by cutting, suggests an association between the female body and mutilation, an association frequent among male homosexuals who, perceiving the woman's body as the castrated body of a man and frightened at the prospect of a similar fate for themselves, are more comfortable with sexual partners who also have penises. Immediately following the passage I have quoted, Ginsberg dramatically shifts the subject, inserting first the Hebrew words of the "Kaddish" (a mourning ritual) and then turning to the story of his father. It is as if the very thought of incestuous wishes immediately provoked thoughts of death and the presence of the father, who might administer just that punishment his son most fears. In fact, in Part I of "Kaddish" Naomi is lamented as a victim who "fought the knife-lost / Cut down" by a heartless father wielding a "sharp icicle" (pp. 10-11). Yet in his recollection of incestuous yearnings, Ginsberg's deepest fears seem inspired less by Louis than by Naomi herself. When he does turn to his father in the succeeding lines, he presents his most poignant picture of Louis: "hurt with 20 years Naomi's mad idealism"-father and son linked as victims of the allpowerful mother (p. 24). Moreover, Naomi"s womb is imagined as "monster" and images throughout the poem reenforce our suspicion that it is a devouring monster. In Part IV Ginsberg speaks of his mother's pubic hair as a "beard" (a trite image of which he is inordinately fond)-as if her vagina were a mouth (p. 34); and in Part II, on his last visit to his mother in the hospital, he imagines the door as a "crotch," on the other side of which lies death. The quotation of the Hebrew words of the "Kaddish" suggest, on the deepest level, Ginsberg's association of incest with death. It is as if, were he to get too close to his mother, she would swallow him upthough he can't finally separate himself from her either. In "Kaddish," as in all of Ginsberg's earlier poetry, the conflict is one of separation versus unity. Separation is never independence but always an absolute, sterile, and frustrating isolation, as in the passage where all members of the family are hysterically screaming at each other yet with each of them locked in a private world of his or her own, incommunicado. The separation is so radical 
that it cannot be resolved by mere verbal or emotional communication ("her own universe-no road that goes elsewhere"); so Ginsberg longs to be delivered from this agonizing isolation by a kind of self-annihilating fusion with the mother. From this point of view we can understand his incestuous desires as expressing Ginsberg's wish to get inside his mother and see things as she does. The progression of Ginsberg's early career, in fact, is toward a closer and closer identification with her paranoid politics, her hallucinatory visions, even her physical sloppiness and sexual "looseness."

In "Kaddish"-as in "Howl"-absolute isolation alternates with absolute fusion, each poem seeking "resolution" in spiritual transcendence, apocalyptic vision, a total fusion that could only be realized in the static perfection of death. As "Kaddish" proceeds, it comes less and less to accept the loss of Naomi, more and more to yearn for union with her in death or, while life remains, to incorporate her vision as the poet's own. "Die / If thou woulds't be with that which thou dost seek," says Shelley in the lines from "Adonais" that Ginsberg significantly chose for his epigraph. The poem not only celebrates death as deliverance from the frightening and frustrating separateness of human life; it also identifies Naomi as the source of that vision of death. In this rich sense Naomi is Allen's inspiration, his "muse."

O glorious muse that bore me from the womb, gave suck first mystic life \& taught me talk and music, from whose pained head I first took Vision-

Tortured and beaten in the skull-What mad hallucinations of the damned that drive me out of my own skull to seek Eternity till I find Peace for Thee, O Poetry-and for all humankind call on the Origin

Death which is the mother of the universe! (pp. 29-30)

In just these few lines, Ginsberg characteristically moves from a celebration of his mother as "glorious muse" to thoughts of her suffocating hold on him, so that in the end she is conflated with Death, at once feared and sought. At first Ginsberg asserts that the real Naomi was not the overweight, scarred, lonely woman locked in a room of a lunatic asylum-but the mother of his earliest memories who fed him physically and spiritually: "gave suck first mystic life \& taught me talk and music"-creating an intimacy so complete that he seemed to see with her eyes. Yet such union of mother and son has its threatening aspect; her vision of things is "pained," and her life suggests to her son that the only way out of suffering is through a kind of immolation in it-by being pained into "Vision." Such destructive-redemptive gestures are repeated throughout Ginsberg's poetry, and they derive not just from a self-punishing masochism, but from the need to find ex- 
periences extreme enough, painful enough, to shatter the boundaries of the separate self. In this passage the modifying phrase "tortured and beaten in the skull" floats free of any precise referrent, allowing it to refer to both Naomi and Allen, joined in suffering, in those moments when they "lose their head." Her suffering, it appears, is his. Yet if such union is hard to bear, so is separation: the curious phrase, "bore me from the womb," makes it sound as if he were cast out from her unwillingly at birth. And this kind of resistance to a life of his own is yet another reason why Ginsberg himself is "tortured and beaten in the skull"-i.e., tortured and defeated when locked in the skull of private consciousness. Here, a sentence that began as an apostrophe to Naomi as "glorious muse" and which we expect to continue as some form of prayer to her breaks off to frame a question ("What mad hallucinations," etc.), a question that in turn is never completed as it turns into an agonized and helpless cry: what drives him to be like her, to lose his head in "mad hallucinations" like her own! The answer is that both her presence and her absence drive him out of his skull: when near, she absorbs him into her vision; but once separated, he is driven to return, and the only way he can return is by sharing her vision-by fusing with her. Either route ends in a kind of death for the separate personality, but Death itself (now his muse) is affirmed as a release from the frustrating boundaries of the self, and as allowing a peaceful and final merge with the mother.

During his mother's seizures the adolescent Ginsberg had tried to break through to her by asserting a realistic point of view ("No wires in the room!'-I'm yelling at her"), a line of approach that ended in rage, frustration, hysteria. But Ginsberg closes the long autobiographical Part II of "Kaddish" by recollecting a moment of communication with Naomi, one that came, "mystically," just after her death. While living in a cottage in Berkeley in 1957, having (he hoped) left familial strifes behind him in the East, Ginsberg dreamed of his mother's spirit-"that, thru life, in what form it stood in that body, ashen or manic, gone beyond joy - / near its deathwith eyes-was my own love in its form, the Naomi, my mother on earth still" and wrote a "long letter" declaring this love "\& wrote hymns to the mad." A few days later he received a telegram from his brother, informing him of his mother's death; and two days after that, he got a letter from his mother, the first he'd had from her in several years-a prophecy (seemingly) from beyond the grave. The letter wonderfully mixes conventional maternal advice with cryptic visionary utterances:

'The key is in the window, the key is in the sunlight at the windowI have the key-Get married Allen don't take drugs-the key is in the bars, in the sunlight in the window.' 
The key, according to the mother, is coventionality: "Get married Allen don't take drugs." But in Part III of the poem Ginsberg picks up on the letter's visionary metaphors, the image of the flash of light that frees the self from the locked room, the pained head-the prison of solitary consciousness.

'The key is in the sunlight at the window in the bars the key is in the sunlight,'

only to have come to that dark night on iron bed by stroke when the sun gone down on Long Island

and the vast Atlantic roars outside the great call of Being to its own

to come back out of the Nightmare-divided creation-with her head lain on a pillow of the hospital to die

-in one last glimpse-all Earth one everlasting Light in the familiar blackout-no tears for this vision-

But that the key should be left behind-at the window-the key in the sunlight-to the living-that can take

that slice of light in hand-and turn the door-and look back see

Creation glistening backwards to the same grave, size of universe, size of the tick of the hospital's clock on the archway over the white door-

Naomi Ginsberg, inmate of asylums for many years now, victim of shock treatments and strokes, locked alone in her room, further isolated by her madness, lies in a "dark night" on an "iron bed" like a prisoner, a kind of prisoner of life. As Ginsberg makes clear, it is not just the harrowing experiences of her life that make it nightmarish, it is the very condition of living in a bounded, physical being-"divided creation"-that creates the "Nightmare." In the midst of all this, Naomi is pained into vision, has her glimpse of "everlasting Light," finds the key to the locked self. Yet the key, as Ginsberg interprets it, is to see physical life, its ordeals, as unreal, a dream -as brief and insignificant as the tick of the hospital clock. The vision does not open, as in a Whitman or a Blake, a harmonizing of physical and spiritual; rather it opts for the apocalyptic, the purely transcendent. The moment of vision, here, is the moment of death; and death is the key, releasing us from the nightmare of a fleshly (and thus divided) existence.

In "Kaddish"'s last two sections, Ginsberg shifts from detailed narrative in long "broken paragraphs" to shorter, more intense liturgical chants which attempt to let go of the memory of Naomi and accept her loss. ${ }^{35}$ Yet the very means by which Ginsberg comes to terms with her death is by identifying as his own that very vision of life as death which she had imposed on 
him from his earliest years. Section IV utters "farewell” to Naomi Ginsberg by cataloguing parts of her body, aspects of her life, that are expressive of her ordeal-as if her life were passing before his mind in final review. As the list proceeds, Ginsberg focuses on her eyes: "with your eyes of shock / with your eyes of lobotomy / with your eyes of divorce / with your eyes of stroke / with your eyes alone / with your eyes / with your eyes" (p. 35). Her eyes convey a kind of mute, helpless suffering and to look into them is to become transfixed, paralyzed by her vision; in fact, the emotional force of this section is not toward a "farewell," but to show the poet mesmerized by the Medusa-like glance of his mother. The poem's final section, likewise liturgical in manner, similarly depicts Ginsberg as helplessly transfixed by the memory of his mother. Section $V$ begins as a visit to Naomi's grave and proceeds by alternating the cries of crows in the cemetery ("caw caw caw") with a religious chant ("Lord Lord Lord"). The crows evoke decomposition, the inevitable fate of life in the flesh, while the "Lord" is intended to define an eternal perspective within which such cruel realities can be accepted. But the poem's final line-"Lord Lord Lord caw caw caw Lord Lord Lord caw caw caw Lord" (p. 36)-conflates crow and Lord, temporal and eternal, as devourers, and the effect of the line, which Ginsberg once described as "pure emotive sound," is that of a cry, or a "howl," of a suffering victim. ${ }^{36}$ Life, with its impersonal physical processes, its movement through a divided and often indifferent world-that world into which Ginsberg was unwillingly cast-is intolerable. Hence, the only way it can be borne is by seeing it through Naomi's eyes-as a "vision":

caw caw all years my birth a dream caw caw New York the bus the broken shoe the vast highschool caw caw all Visions of the Lord (p. 36, my italics).

Whatever its agonies, life is merely a dream in the mind of an omnipotent Lord-a thought that, it seems, offers safety, if not selfhood. Yet it is the threatening qualities of this divinity which are stressed ("great Eye that stares on All," "Grinder of giant Beyonds"-p. 36) and it is clear that this "Lord," with his powerful glance and his threat to devour, is ominous in precisely those ways Naomi is. In fact, all the poem's deific figures-the glorious muse, omnipotent Lord-dissolve into a single figure, "the Naomi," who is the "Origin/Death"-the "fatal Mama."

A key result of the psychic conflict in the poem is a kind of formal tension. In seeking to link confessional and visionary modes, Ginsberg was advancing a poetic project that had begun with "Howl" and that would prove to be a generative one for contemporary poetry. Yet autobiographical and mystical motives are at odds with each other in "Kaddish." If Part II confronts us with a relentless "release of particulars" into powerful narrative, 
all remaining sections of the poem strive to chant those particulars into dream, Vision-a strategy that fails on at least two counts. In the first place, the need of the poet to get 'out of his head' in many respects signals a surrender to, rather than coming to terms with, the memories of Part II. In addition, most readers will, I think, leave the work more impressed with the psychic conflicts of II than the sought resolutions of the closing sections. Moreover, Ginsberg's account of the poem's composition in "How Kaddish Happened" implies the centrality of the second part and reveals that Ginsberg felt that he was in some sense "defeated" by the poem-i.e., by Naomi. ${ }^{37}$ While individual sections of "Kaddish" were written spontaneously, some of them in drug-induced moments of "mad hallucination," long intervals separated the writing of these sections, the whole poem taking more than two years. Significantly, the order of composition went: first, part IV (the evocation of Naomi's mesmerizing stare), then a year later I and II, then some indefinite period after this, V; no mention is made of III. Most emphasis is given in the essay to the writing of II, which Ginsberg approached slowly, resistingly, yet felt he had to approach; Part II was written in 20 straight hours of effort after a night of no sleep, some mescaline and speed, listening to Ray Charles records and chanting aloud passages from Shelley's "Adonais" and the Hebrew "Kaddish": Afterward,

I walked out in early blue dawn on to 7th Avenue \& across town to my Lower East Side apartment-New York before sunrise has its own celebrated hallucinatory unreality. In the country getting up with the cows and birds hath Blakean charm, in the megalopolis the same nature's hour is a science-fiction hell vision, even if you're a milkman. Phantom factories, unpopulated streets out of Poe, familiar nightclubs bookstores groceries dead. ${ }^{38}$

The essay's title, "How 'Kaddish' Happened," implies that the poem happened to Ginsberg, surfacing from the depths of his buried self-a familiar claim of romantic poets but one that here carries the added suggestion that the poem was thrust upon a somewhat resistant poet. At the same time Ginsberg's account of the writing of the poem depicts the poet-via exhaustion, drugs, and careful selection of urban setting and suitably elegiac literary texts-deliberately flaggelating himself into vision, into communing with his dead mother. Both versions, of course, are true-true to his divided fear of and longing for the woman who gave him "mystic life." What Ginsberg sees when he wanders down 7th Avenue at dawn is the city seen through Naomi Ginsberg's terrified eyes; and it is also a landscape of loss -what life looks like to him without her: a hell vision of unbearable isolation in a cold, threatening environment. 
After finally getting down a draft of the entire poem, Ginsberg tells us, he waited another year before even typing the manuscript, much less seeking publication. The poem seemed, he recalls, too massive, too messy and too private to reach an audience, suggesting that on an unconscious level the writing of the poem may have been an act of private communication between the poet and his "muse," like the letter he had received from her just after her death. In any case, "Kaddish," all too successfully recreating the overwhelming size, disorder, and inaccessibility of its subject, seemed to have "defeated" its author.

In these self-doubts we can hear the internalized voice of Louis Ginsberg, the side of Ginsberg that feared that identification with his mother's way of seeing things would leave him, like her, trapped in a private vision, with "no road that goes elsewhere." At this point, Ginsberg, showing that he may have derived more strength from the father than he liked to admit, sat down to the "patient scholar's task" of making the poem "shapely." ${ }^{9}$ If he began by trying to bring the father's "dead" medium back to life by infusing it with the visions of his mother, it was his commitment to poetry that turned Ginsberg back toward the world, opened a road that did span the gap between private vision and external reality.

Of course, what Ginsberg himself stresses in his account of the composition of "Kaddish" is the need to go "all the way out" in order to capture a "continuous impulse," an emotional and creative thrust that would be stifled in a more orderly work. ${ }^{40} \mathrm{In}$ his view, poetic (and human) energy can only be generated by going out of one's skull-beyond the "dead forms" of reality and back to the Origin, the mother, who turns out to be Death. On a human level such regressive longings mark a kind of defeat, at least the defeat of the quest for independence, for a life of one's own. Yet "defeat like that is good for poetry," Ginsberg states.

-you go so far out you don't know what you're doing, you lose touch with what's been done before by anyone, you wind up creating a new poetry-universe. "Make It New," saith Pound, "Invention," said W. C. Williams. That's the "Tradition"-a complete fuck-up so you're on your own. ${ }^{41}$

Such defeat does not guarantee good poetry; but in the literary atmosphere of the late 1950s-dominated by poetry that was self-consciously impersonal and traditionalistic-Ginsberg's breaking of established boundaries released a new life into contemporary American poetry.

For help in writing this essay I am indebted to Dr. Felix Ocko and Margaret Darby, both of Berkeley, California. 


\section{NOTES}

1Robert Creeley cites the new sense of form in "Howl" in his "Introduction to The New Writing in the USA," A Quick Graph (San Francisco, 1970), pp. 44-45 as do Galway Kinnell in "The Poetics of the Physical World," Iowa Review, II (Summer 1971), 115-16, and Adrienne Rich, "Talking with Adrienne Rich," The Ohio Review, XIII (Fall 1971), 28-46.

2 All of these journals are part of the Allen Ginsberg Archives at Columbia University. Quotations from material in the collection are made with the kind permission of Allen Ginsberg and Columbia University.

3 Starting from San Francisco (New York, 1967), p. 27.

4 Jane Kramer, Allen Ginsberg in America (New York, 1970), pp. 39-40.

5 Ibid., p. 42.

6 See "Notebook, 1953-56" in the Allen Ginsberg Archives for information on this period in Ginsberg's life.

7 Entry for April 20, 1955 in "Notebook 1953-56."

8 Allen Ginsberg in America, p. 42.

9 Young Man Luther (New York, 1958), p. 103.

10 Allen Ginsberg in America, pp. 150-51.

11 Go (New York, 1952), p. 108. The statement about accuracy is made in Holmes' Nothing More to Declare (New York, 1967), p. 56.

12 Louis Ginsberg to Allen Ginsberg, August 8, 1945, in the Allen Ginsberg Archives. All subsequent correspondence cited is also from the Archives.

13 Louis Ginsberg to Allen Ginsberg, December 12, 1955.

14 Louis Ginsberg to Allen Ginsberg, n.d.

15 Louis Ginsberg to Allen Ginsberg, November 2, 1945.

16 Louis Ginsberg to Allen Ginsberg, October 29, 1945.

17 Louis Ginsberg to Allen Ginsberg, November 2, 1945.

18 Ibid.

19 Louis Ginsberg to Allen Ginsberg, March 10, 1958.

20 "Terse," in Morning in Spring and Other Poems (New York, 1970), p. 119.

21 Louis Ginsberg to Allen Ginsberg, November 2, 1945.

22 Louis Ginsberg to Allen Ginsberg, n.d. (but probably sometime in 1948).

23 Ibid.

24 Louis Ginsberg to Allen Ginsberg, March 10, 1958.

25 Louis Ginsberg to Allen Ginsberg, May 27, 1956.

26 Louis Ginsberg to Allen Ginsberg, July 11, 1948.

27 Allen Ginsberg to Louis Ginsberg, September 3, 1947.

28 Paterson News, Monday, June 2, 1969, p. 4.

29 Allen Ginsberg to Louis Ginsberg, n.d. (but probably sometime in 1948).

30 Allen Ginsberg to Louis Ginsberg, September 3, 1947.

31 "Confrontation with Louis Ginsberg's Poems," in Morning in Spring, p. 11. Subsequent references are made in the text.

32 "How 'Kaddish' Happened," in The Poetics of the New American Poetry, ed. Donald Allen and Warren Tallman (New York, 1973), p. 347.

33 Morning in Spring and Other Poems, p. 93.

34 Kaddish and Other Poems, (San Francisco, 1961), p. 13. Subsequent references are made in the

35 "How 'Kaddish' Happened," p. 345.

36 Ibid., p. 346. 
37 Ibid.

38 Ibid., p. 345.

39 Ibid., p. 346.

40 Ibid.

41 Ibid. 